\title{
A KEY TO THE SPECIES OF SPINTHARINA WITH DESCRIPTIONS OF NEW SPECIES AND INDICATION OF SPECIES GROUPS (HYMENOPTERA, CHRYSIDIDAE)*
}

\author{
BY RICHARD M. BOHART \\ Department of Entomology, University of California, \\ Davis, CA 95616
}

Spintharina Semenov (type species: vagans Radoszkowski occurs in the southern Palearctic and Ethiopian Regions. This group is characterized by the absence of teeth on tergum III, a long triangular forewing marginal cell, and an apically blunt or emarginate lateral propodeal projection. Fragmentary evidence points to Masaridae as hosts. I have been able to study types or authentically determined specimens of 23 of the 26 species. Status of the other 3 is in doubt. Complete synonymy and distribution will be given in a generic revision of Chrysididae now in preparation by L. S. Kimsey and R. M. Bohart. I would like to thank Dr. Kimsey for turning over to me her basic research on the genus, and for reviewing this paper.

Technical terms used in the key and descriptions are: F-I etc., flagellomeres; T-I etc., terga; S-I etc., sterna; MOD, midocellus diameter.

Type material has been studied at or borrowed from most of the important European and South African Museums. Acknowledgements will be made in the aforementioned revision.

\section{KEY TO SPINTHARINA}

1. Hindtibia on outer surface with a whitish basal band (fig. 4), malar space slightly more or less than 1.0 MOD, T-III basolaterally with a moderate convexity at most, male F-I-II brilliant white in front (fig. 3) (males unknown in poecilopus, cyanophris, and apiculata), (cyanophris group); S. Africa.. 2

Hindtibia on outer surface dark basad, malar space and T-III basolaterally various, male F-I-II usually dark ........7

*Manuscript received by the editor February 16, 1987. 
2. Body dorsum mostly green, a little purplish on propodeum and T-III postpit ................... arnoldi (Brauns) Body not mostly green dorsally ...................

3. Mesopleuron green overlaid with coppery

poecilopus (Mocsáry)

Mesopleuron not coppery.......................4

4. Lower mesopleuron extensively polished, T-III apex broad and a little indented medially (male only known)

albata (Edney)

Lower mesopleuron mostly sculptured-punctate, T-III apex somewhat pointed medially ...................

5. Hindtibia white on basal $1 / 3$ of outer surface (fig. 4) ........ bispinosa (Mocsáry)

Hindtibia white on basal $1 / 4$ of outer surface ...........6

6. Scutellum, metanotum, and pleuron reddish to coppery ...... apiculata (Mocsáry) Scutellum, metanotum and pleuron purple with a little green

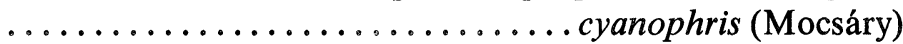

7. T-III with a conspicuous translucent distal strip nearly all around (figs. 8, 10), male F-I-II together about as long as III (fig. 10) (vagans group) ..................... 8

T-III without a translucent strip, or such strip broken medially, or extreme edge only translucent; male F-I-II not unusually

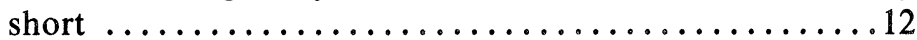

8. T-III basolaterally with an angled swelling or large lobe (fig. 8)

T-III basolaterally with at most a low, broadly rounded swelling 10

9. Scutal midsection with a strong longitudinal furrow, malar space shorter than F-IV, TFC angulate, basolateral lobe of T-III quite prominent; Ethiopia, Mideast

invreai Zimmermann

Scutal midsection not furrowed, malar space as long as F-IV, TFC crescentic, basolateral lobe of T-III a low angular lobe; s. Palearctic Region............ vagans (Radoszkowsky)

10. Scutum with a pretegular hook (fig. 7), translucent rim of T-III pale brownish, Israel ..............houskai (Balthasar) Scutum without a pretegular hook, translucent rim of T-III practically white.........................11 
11. Body nearly all bluish purple (fig. 10), United Arab Emirates dubai Bohart Body bright green, terga extensively coppery (fig. 9), Senegal ............................. senegalae Bohart

12. T-III basolaterally with a somewhat angled swelling (fig. 5), T-III apex rather smooth but concolorous reddish or coppery with rest of terga (versicolor group) ...............13

T-III basolaterally nearly straight or somewhat convex but not angled, apex various ....................... 15

13. Malar space shorter than subantennal space; male F-I slightly longer than pedicel, a little longer than II but shorter than III; T-III basolaterally with a promiment, partly rounded lobe (fig. 5); United Arab Emirates ............ sugdeni Bohart Malar space longer than subantennal space; male F-I $1.5 \times$ as long as pedicel, longer than II or III; T-III basolaterally with a flattened, obtusely angled lobe ................14

14. Pits of T-III in a narrow groove, and rounded (S. Palearctic Region) .................... versicolor (Spinola) Pits of T-III more impressed, elongate

agadirensis Buysson

15. Malar space 1.7-2.3 MOD, at least as long as subantennal space (innesi group) ...........................

Malar space 0.9-1.2 MOD (fig. 1) (pleuralis group).......20

16. Lower mesopleuron rounded under, not denticulate ......17

Lower mesopleuron somewhat expanded, weakly to strongly denticulate ..............................18

17. Medial vein curved sharply as it approaches cu-a, terga bright coppery, TFC distinct; Mideast ... appendiculata (Buysson)

Medial vein gently curved as it approaches cu-a, terga green with coppery tint, TFC obsolescent; s. USSR ...

tenellula (Semenov)

18. Male face with fine crossridging in middle third, not densely silver setose; male F-I apex, F-II-III contrastingly light tan, flagellomeres somewhat nodose within (fig. 2); female unknown; S. Africa ................. edneyi Bohart

Male or female face not obviously crossridged, densely silver setose in male; flagellum in male not bicolored, flagellomeres nodose or simple .........................19

19. Punctures below midocellus elongate, somewhat striatiform; 
flagellomeres of male not nodose; T-III indented apicomedially; Egypt ............... cornigera Zimmermann Punctures below midocellus not elongate, flagellomeres of male nodose within, T-III not indented apicomedially; Spain, Morocco, Sinai ................ innesi (Buysson)

20. Terga mostly coppery red, face with at least some bright coppery ....................................21

Terga green to purple, face various ..............22

21. T-III pit row indistinct, not indented, postpit area all coppery and punctured as in rest of terga (fig. 6), face and pleuron all bright coppery; S. Africa ........... postpunctata Bohart

T-III pit row distinct and well indented, postpit area partly micropunctate and shiny, face partly green, pleuron green; $S$. Africa ....................... pleuralis (Mocsáry)

22. Head, notum, and pleuron coppery to red; S. Africa ........ polychroma (Mocsáry)

Head, notum, and pleuron mostly green (fig. 1); S. Africa..... kimseyae Bohart

Notes on species not included in the key

S. bleuthgeni (Linsenmaier) 1959: 102. Holotype male; Jordan: Jerico (LUZERN). Similar to versicolor according to Linsenmaier. Flagellum nodose.

a S. integerrima (Klug) 1845: pl. 45, fig. 14. "Arabia"(BERLIN?). Similar to versicolor according to Mocsáry 1889.

S. obscuriventris (Linsenmaier) 1968: 57. Holotype female; Greece (LUZERN). Similar to versicolor according to Linsenmaier.

Spintharina dubai Bohart, new species

Holotype male. Length $5.5 \mathrm{~mm}$. Stout; bright purple with faint green tinges, tarsi and postpit rim of T-III whitish, wings nearly clear; scapal basin densely silver setose except narrow median line; punctation moderately coarse and close, weak on clypeus, practically absent on T-III postpit; F-I as broad as long, F-I and II together a little longer than III (fig. 10); malar space 1.5 MOD, subantennal space 1.0 MOD; TFC sharp, slightly irregular but nearly straight; midocellar area weakly defined, a little depressed; mesopleuron sharply tridentate below polished scrobal sulcus; propodeal projection stout, emarginate truncate (as in fig. 1), T-II and III with a 
weak median longitudinal carina; T-III convex basolaterally, pit row distinctly impressed, pits somewhat elongate (fig. 10), apical rim convex; S-II spots round, broadly separated.

Female. As in male but F-I 1.6X as long as broad, 1.2X as long as II or III.

Male holotype and 9 male, 5 female paratypes, Dubai, United Arab Emirates, IV-18-84 (some paratypes are months I, II, V, and VII), E. A. Sugden (U. C. Davis).

Discussion. The continuous whitish distal margin of T-III and the short male F-I-II place dubai in the vagans group.

\section{Spintharina senegalae Bohart, new species}

Holotype female. Length $5.5 \mathrm{~mm}$. Bright green, terga extensively coppery to red, apical rim of T-III whitish translucent, tarsi light brown, legs otherwise green, wings nearly clear; scapal basin silvery pubescent in lateral third, medially punctate and crossridged (fig. 9); punctation otherwise moderate and close but weak on clypeus and absent on T-III postpit; F-I $1.5 \times$ as long as broad, slightly longer than pedicel, F-II or F-III; malar space 1.7 MOD, subantennal space 1.3 MOD; TFC sharp; weakly parenthesis-like; midocellar area slightly depressed; mesopleuron with 3 angles or teeth below polished scrobal sulcus; propodeal projection truncate and apex a little emarginate; T-III convex basolaterally, pit row distinctly impressed, pits slightly elongate, apical rim convex; S-II spots rounded, separated by nearly 2 MOD.

Female holotype. Savoigne, Senegal, III-9-76, G. Couturier (U. C. Davis).

Discussion. The continuous whitish translucent margin of T-III places senegalae in the vagans group. The green and coppery-red terga separate it from dubai.

\section{Spintharina sugdeni Bohart, new species}

Holotype male. Length $6 \mathrm{~mm}$. Stout; head, thorax and sterna bright green, terga coppery with a greenish tint, tarsi pale brownish, legs otherwise green, wings nearly clear; scapal basin all silver pilose except a narrow median line of punctation and crossridging; punctation moderate and rather close but small on clypeus and absent on T-III postpit, forefemur well punctate above a ventral ridge; F-I 
$1.4 \times$ as long as broad, a little longer than pedicel or F-II, slightly shorter than F-III (fig. 5); malar space 1.5 MOD, subantennal space 1.7 MOD; TFC sharp and broadly M-shaped; midocellar area depressed and weakly delimited; mesopleuron tridentate below areolate scrobal sulcus; propodeal projection stout, truncate; T-III with an angular basolateral projection (fig. 5), pit row weakly impressed, pits long oval; apical rim convex; S-II spots nearly confluent.

Female. As in male. F-I about $1.5 \times$ as long as broad, slightly longer than pedicel, F-II or III; F-II very slightly shorter than F-III.

Male holotype. Zabeel, Dubai, United Arab Emirates, I-27-79, E. A. Sugden (U. C. Davis). Paratypes, 18 males, 4 females, Zabeel, Dubai, United Arab Emirates, I-IV, 1984-5, E. A. Sugden; 1 female, Amir, United Arab Emirates, V-2-84, E. A. Sugden.

Discussion. The prominent basolateral swelling and concolorous T-III place sugdeni in the versicolor group, where it is distinct in having the subantennal space longer than the malar space. The species is named for Evan Sugden, who collected a large number of Chrysididae in Dubai.

Spintharina edneyi Bohart, new name

Chrysis (Gonochrysis) rubescens Edney 1952: 446. Holotype male, "Springbok, Namaqualand," South African (South African Museum, Capetown). Nec Radoskowski 1880.

I have seen the type which is a Spintharina in the innesi group. In addition to the relatively long malar space the flagellum is somewhat nodose and bicolored (fig. 2). The scapal basin is plainly microridged in the middle third. T-III is broad with a slight apicomedial indentation. The new name is given in honor of $\mathrm{E}$. B. Edney, who published extensively on South African Chrysididae.

\section{Spintharina postpunctata Bohart, new species}

Holotype female. Length $5.5 \mathrm{~mm}$. Bright reddish coppery with tinges of green on scutellum and metanotum, sterna green and coppery, wings lightly stained; scapal basin lightly silver setose on outer fourth, middle half epunctate and microridged; other punctation moderate, slightly separated, continued evenly to apex of T-III; F-I $2.5 \times$ as long as broad, nearly twice as long as pedicel, F-II or 
III; malar space 1.0 MOD; subantennal space 1.4 MOD; TFC irregular, midocellar area depressed, limited below; mesopleuron tridentate below areolate scrobal sulcus; propodeal projection with a slanting apical truncation (fig. 6); T-II and III weakly ridged at middle; T-III with a low basolateral convexity, pit row hardly indented, pits nearly obsolete, postpit area well punctured (fig. 6), apical rim convex; S-II spots weakly defined, well separated.

Female holotype. Jackkalwater, "Bushmanland," Namaqualand, South Africa, Lightfoot Coll. (Transvaal Museum, Pretoria).

Discussion. The short malar space, unbanded tibiae, and discrete microridging of the scapal basin place postpunctata in the pleuralis group. As in polychroma, the face is all coppery, but the nearly obsolete pit row, well punctate postpit area (fig. 6), and all coppery terga are distinguishing.

\section{Spintharina kimseyae Bohart, new species}

Holotype female. Length $6 \mathrm{~mm}$. Head and thorax green, terga purple, sterna brown and purple, legs purple to green, wings faintly stained; pubescence pale, inconspicuous; punctation moderately coarse, less so on head, outer fourth of scapal basin finely punctate, middle half microridged (fig. 1); F-I 2.9X as long as broad, nearly twice as long as pedicel, F-I or II; malar space 1.1 MOD; subantennal space 1.7 MOD; TFC broadly M-shaped, not strong; midocellar area weakly depressed, hardly limited; mesopleuron tridentate below coarsely punctate scrobal sulcus; propodeal projection emarginate truncate (fig. 1). T-III straight basolaterally, pit row well indented, pits large and nearly round, apical rim slightly angled but rounded at tip (fig. 1); S-II spots slightly separated, not clearly defined.

Female holotype. Worcester, Karoo Gardens, Cape Province, South Africa, IX-29-75, R. M. Bohart (U. C. Davis).

Discussion. The short malar space, unbanded tibiae, and microridged middle half of the scapal basin place kimseyae in the pleuralis group. The T-III roundly pointed shape is much like that of pleuralis and polychroma, both of which have the thorax bicolored copper and green instead of green and a little purple as in kimseyae. The species is named for Lynn Kimsey, who has contributed a great deal to our knowledge of Chrysididae. 


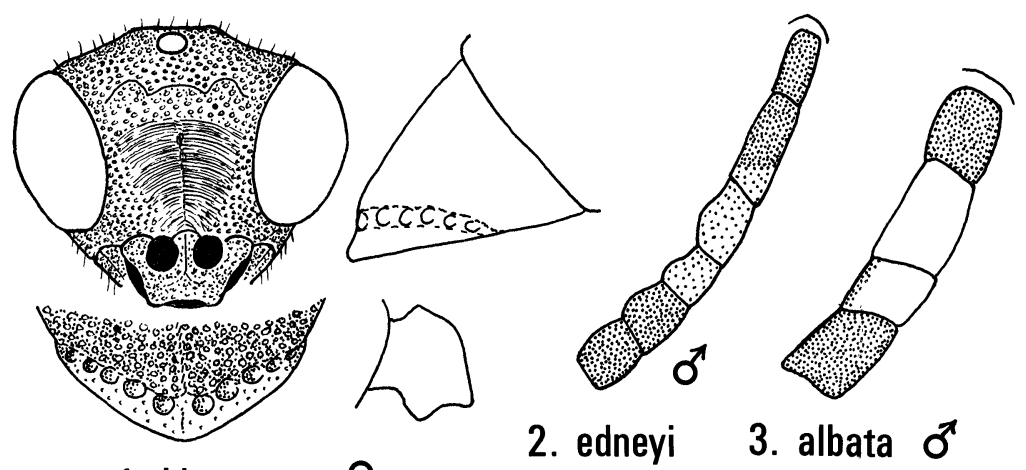

1. kimseyae $q$

\section{2. edneyi 3. albata $\sigma^{\pi}$}

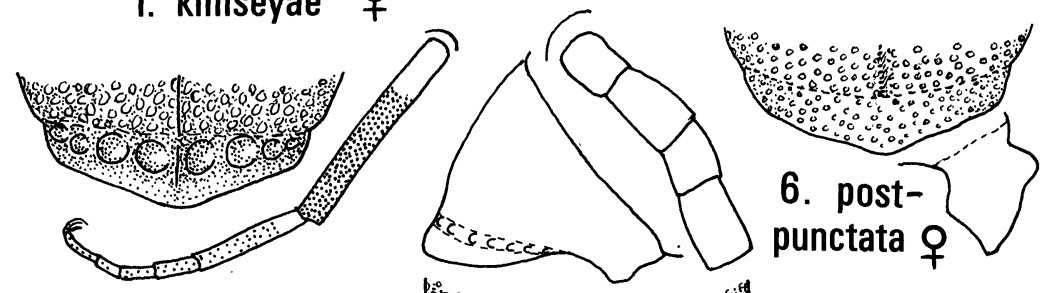

4. bispinosa 9
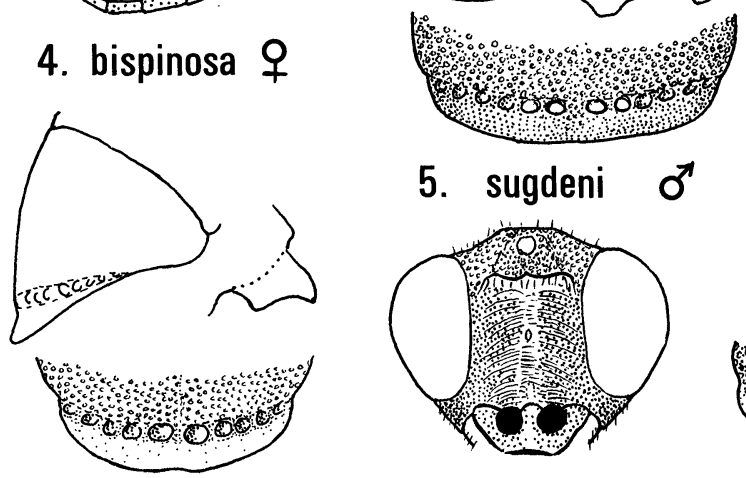

5. sugdeni $\sigma^{\top}$

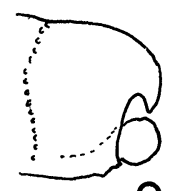

8. vagans $q$

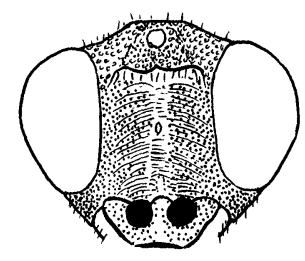

7. houskai $q$
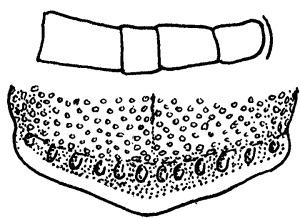

9. senegalae 우

10. dubai $\sigma^{7}$

Fig. 1, face, T-III lateral and dorsal, right propodeal projection. Figs. 2, 3, pedicel and basal flagellomeres. Fig. 4, T-III; hindtibia and hindtarsus. Figs. 5, 8, T-III lateral and dorsal; pedicel and basal flagellomeres. Fig. 6, T-III and right propodeal projection. Fig. 7, scutum (right side) and tegula. Fig. 9, face. Fig. 10, pedicel and basal flagellomeres; T-III apex. 


\section{SUMMARY}

A key is given to 23 species of Spintharina. New species described are dubai and sugdeni from United Arab Emirates; senegalae from Senegal; and postpunctata and kimseyae from South Africa. A replacement name is edneyi for the homonymous rubescens. 

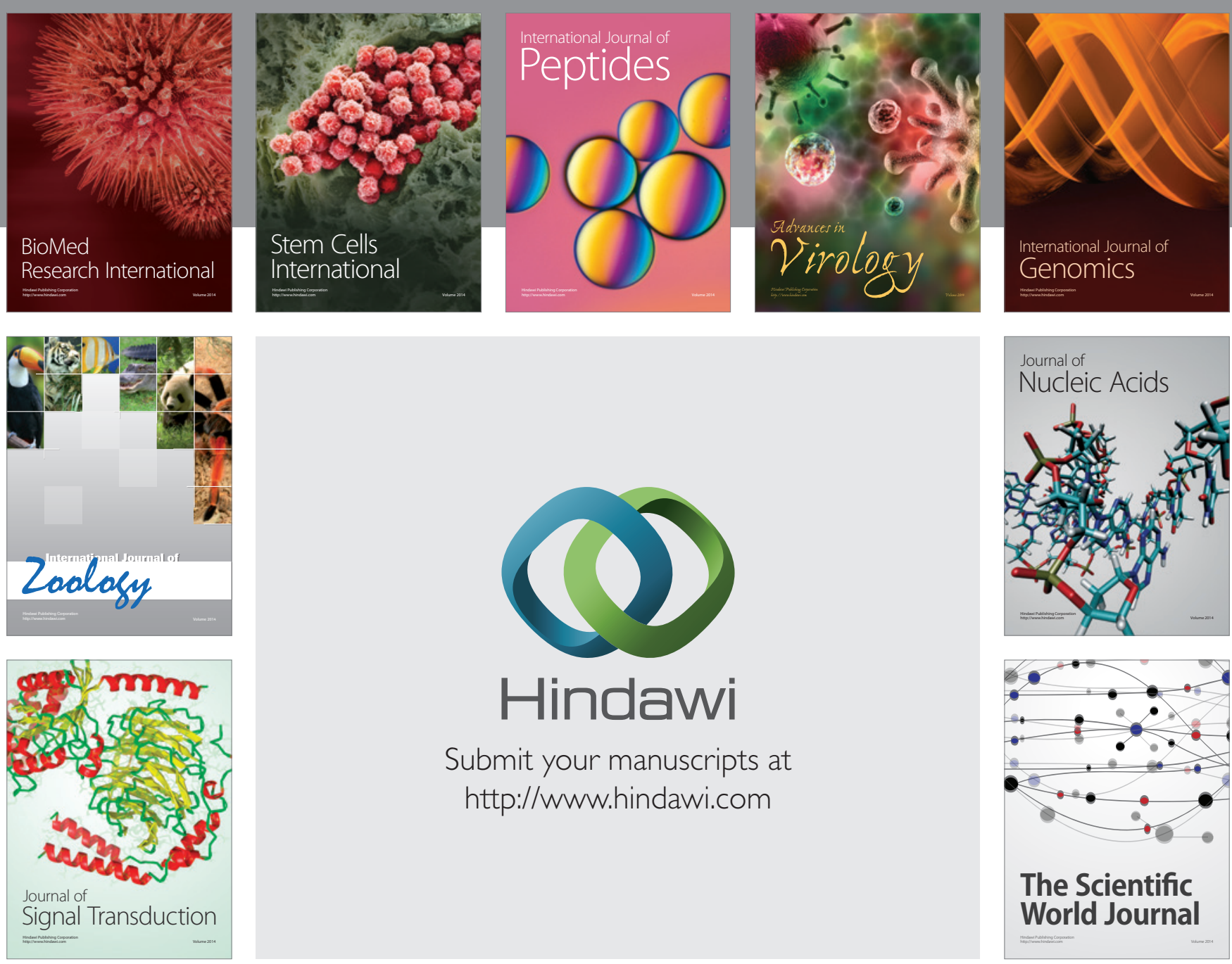

Submit your manuscripts at

http://www.hindawi.com
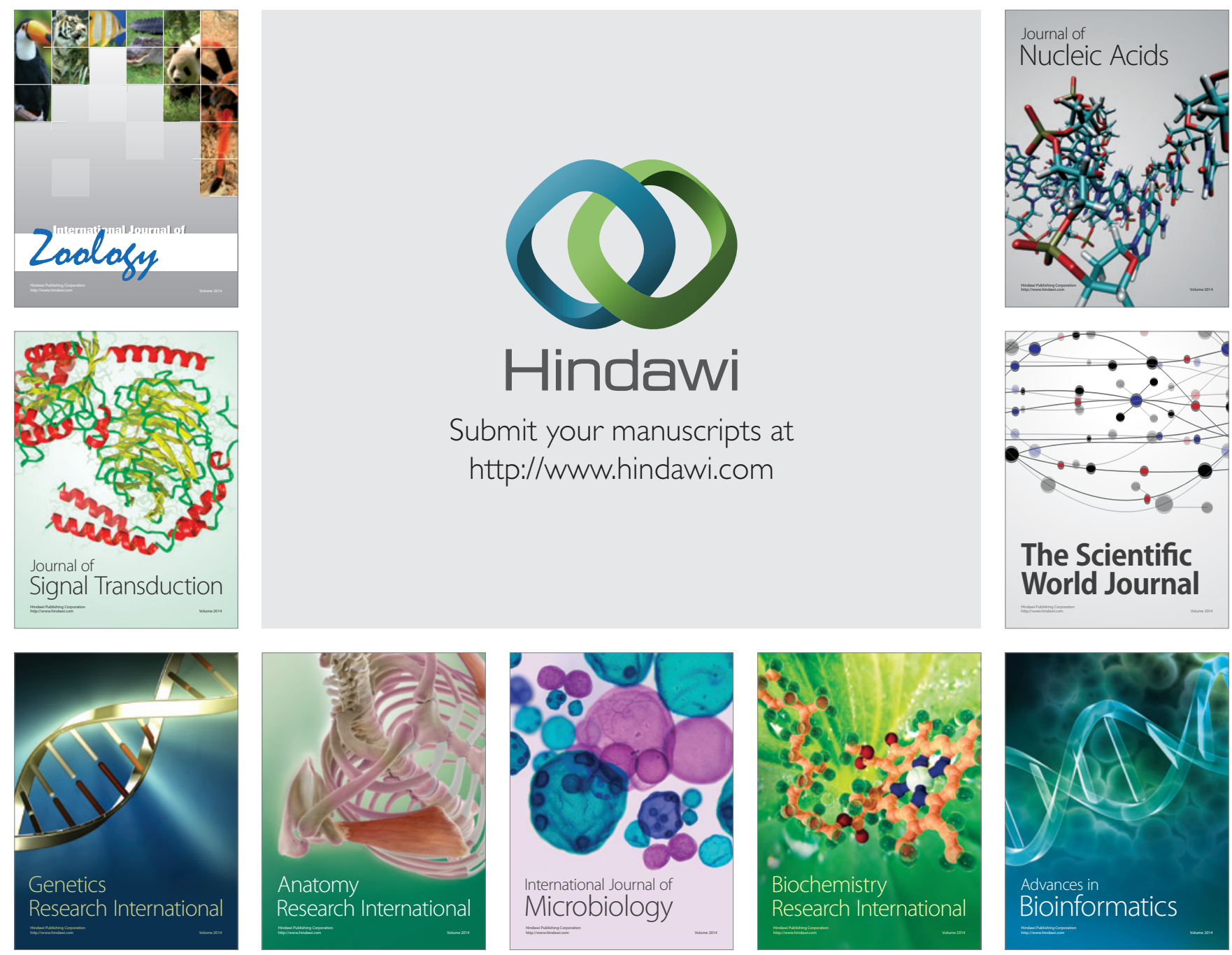

The Scientific World Journal
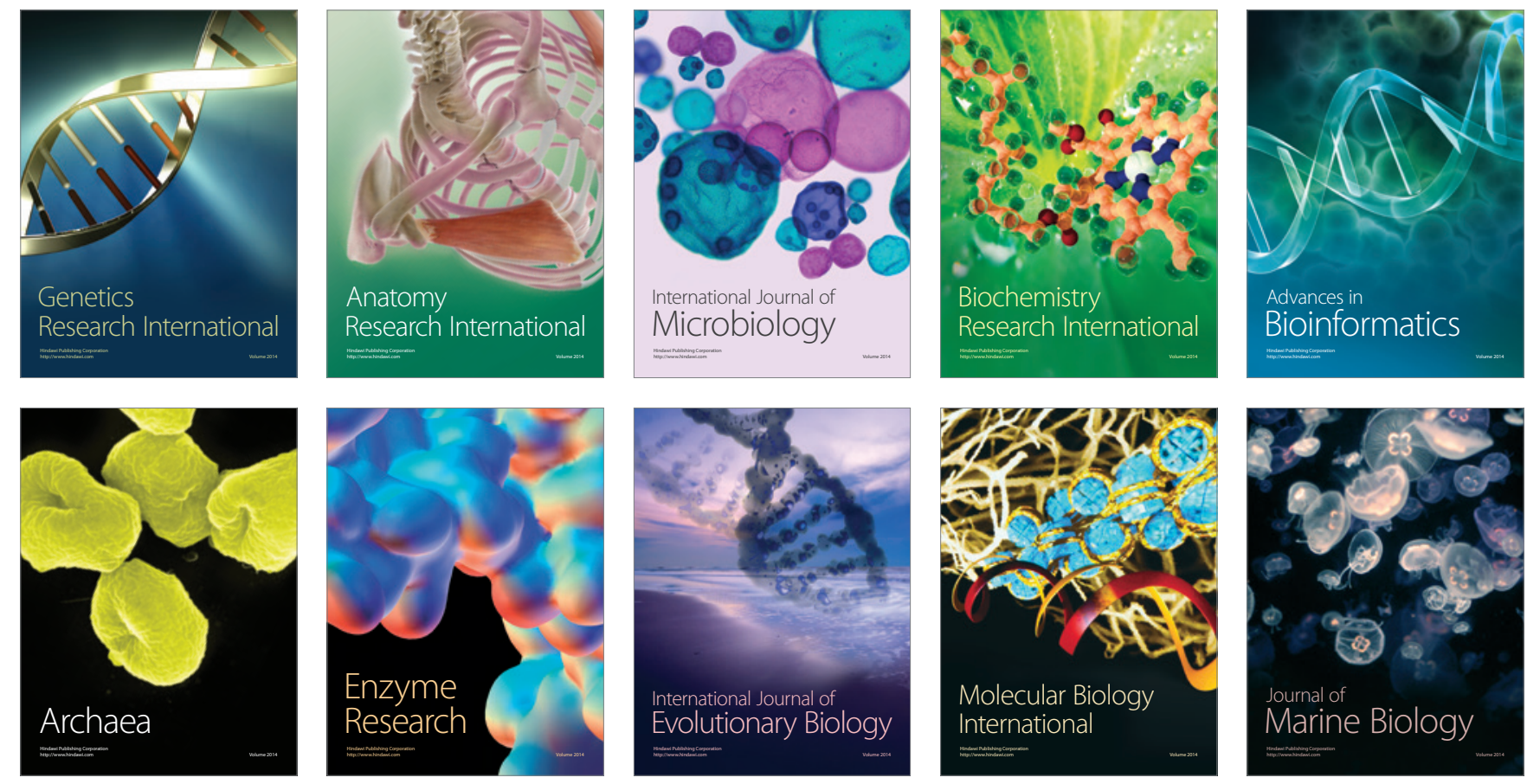